\title{
Acquired thrombotic thrombocytopenia purpura associated with severe ADAMTS13 deficiency in a 3-year-old boy: a case report and review of the literature
}

Hamidah Alias ${ }^{1 *}$, Woon Lee Yong ${ }^{2}$, Farah Azima Abdul Muttlib², Ho Wai Koo ${ }^{1}$, C-Khai Loh', Sie Chong Doris Lau', Hafiza Alauddin² and Raja Zahratul Azma

\begin{abstract}
Background: Acquired thrombotic thrombocytopenia purpura is very rarely encountered in children. It is often misdiagnosed initially when the condition is not inherited.

Case presentation: We describe a 3-year-old Malay boy who presented with simple febrile seizure and had no neurological deficit, however, he was found to have microangiopathic hemolytic anemia, thrombocytopenia, and elevated serum lactate dehydrogenase. An ADAMTS13 assay results showed zero activities (0\%), and markedly high level of ADAMTS13 inhibitor $(93.15 \mathrm{U} / \mathrm{mL})$ confirming the diagnosis of secondary thrombotic thrombocytopenia purpura. He received fresh frozen plasma infusions for 3 days and subsequently his platelet levels normalized. Serial ADAMTS13 assay results showed improvement. He was also given a short course of prednisolone after which the ADAMTS13 activity normalized (>114\%) at the end of prednisolone course.

Conclusions: At presentation, acquired thrombotic thrombocytopenia purpura in a very young child is commonly misdiagnosed as other conditions like idiopathic thrombocytopenic purpura, Evans syndrome, atypical hemolyticuremic syndrome, or malignancy. ADAMTS13 assay should be performed early when thrombotic thrombocytopenia purpura is suspected as this condition is associated with dire consequences.
\end{abstract}

Keywords: Thrombotic thrombocytopenia purpura, ADAMTS13 deficiency, Children

\section{Background}

Acquired thrombotic thrombocytopenia purpura (TTP) is very rare in children, and this condition is due to severe deficiency of disintegrin and metalloproteinase with a thrombospondin type 1 motif, member 13 (ADAMTS13) activity. TTP is characterized by microangiopathic hemolytic anemia (MAHA), thrombocytopenia, and elevated serum lactate dehydrogenase (LDH). Diagnosis of TTP is confirmed by the measurement of a serum ADAMTS13 activity level of $<10 \%$ (normal range, $40-$ $130 \%)$ or undetectable in the acute phase [1-3]. ADAMTS13 is a family of 19 metalloprotease enzymes,

\footnotetext{
* Correspondence: midalias@ppukm.ukm.edu.my

${ }^{1}$ Department of Pediatrics, UKM Medical Centre, Faculty of Medicine, The

National University of Malaysia, Cheras, 56000 Kuala Lumpur, Malaysia

Full list of author information is available at the end of the article
}

and is responsible for cleaving the ultra-large von Willebrand factor (vWF) released from endothelial cells, hence, reducing the vWF multimeric size $[2,4,5]$. A functional deficiency of ADAMTS13 can cause accumulation of the ultra-large vWF in the plasma, thus forming platelet thrombi within the microcirculation. As a result, consumptive thrombocytopenia, mechanical hemolytic anemia, and multi-visceral ischemia can occur [2-4]. Congenital TTP is due to ADAMTS13 gene mutation (Upshaw-Schulman syndrome) that usually presents with severe jaundice and thrombocytopenia in the neonatal period. Acquired TTP is frequently due to autoimmune formation of specific anti-ADAMTS13 autoantibodies, and anti-ADAMTS13 immunoglobulin G (IgG) should be investigated to confirm the diagnosis $[2,4]$.

(c) The Author(s). 2018 Open Access This article is distributed under the terms of the Creative Commons Attribution 4.0 International License (http://creativecommons.org/licenses/by/4.0/), which permits unrestricted use, distribution, and 
The primary aim of this report is to highlight that acquired TTP should be suspected in a very young child who presents with febrile seizure without evidence of neurological findings, and has MAHA, thrombocytopenia, and elevated serum LDH. A high index of suspicion is required to diagnose this condition in children. Plasma infusion and corticosteroid treatment successfully induced complete remission in this patient despite not receiving standard treatment of plasmapheresis.

\section{Case presentation}

Our patient was a 3-year-old Malay boy, who presented with fever of 2 days' duration and an episode of generalized tonic-clonic seizure that lasted approximately $5 \mathrm{mi}-$ nutes. There was no up rolling of eye ball or drooling of saliva during the seizure. He had post-ictal drowsiness for 10 minutes. There were no other associated symptoms. Six weeks prior to the presentation he was brought to a general practitioner for fever and skin rashes over his face and upper limbs. He was treated with orally administered paracetamol and cefuroxime axetil. Subsequently, the fever resolved but the skin rashes persisted. On admission, he was diagnosed as having simple febrile seizure and eczema herpeticum. At 13 months of age he was diagnosed as having single gene deletion $\alpha$-thalassemia trait $(\alpha \alpha /$ $-\alpha 4.2)$, and remained asymptomatic since diagnosis. His parents were non-consanguineous. His mother is 35-years old and has $\alpha$-thalassemia trait. There was history of right ear infection a year before and that had resolved with treatment. He has history of allergy and intermittently was on orally administered desloratadine. There was no other significant past medical history, and he was not on any other medicine prior to the recent presentation. His immunization status was up to date, and developmentally he was normal. He lived with his parents who worked as police officers, and he has another healthy younger sibling of 5-months old. They lived in an apartment in a suburban area. He went to kindergarten when the parents worked.

On admission, a physical examination revealed Glasgow Coma Scale of $15 / 15$, blood pressure $90 / 46 \mathrm{mmHg}$, pulse rate $120 /$ minute, and temperature $37.9^{\circ} \mathrm{C}$. He was febrile, pale, with no jaundice, and he had "shotty" cervical lymph nodes. The results of examinations of his throat, tonsils, and ears were normal. Some maculopapular rashes with scaly and crusted areas were noted on his left cheek, both arms and knees, and trunk area. There was hepatosplenomegaly of $4 \mathrm{~cm}$ and $3 \mathrm{~cm}$, respectively. There were no bleeding tendencies or neurologic deficit noted. Laboratory findings showed hypochromic microcytic anemia, thrombocytopenia, reticulocytosis, and raised serum LDH. A peripheral blood smear showed significant fragmented red cells, spherocytes, and polychromasia in keeping with MAHA (Fig. 1). Serial investigation results showed persistent anemia and thrombocytopenia. His renal function test, liver function test, and coagulation profile were normal (Table 1). Direct and indirect Coombs tests were negative (Table 2). He was started on orally administered acyclovir for 10 days and received a course of cloxacillin for the rashes. TTP was suspected at this juncture. He was clinically asymptomatic, and was observed without any intervention prior to the results of ADAMTS13 assay. Subsequently, the ADAMTS13 assay results showed zero activities (0\%) and markedly high level of ADAMTS13

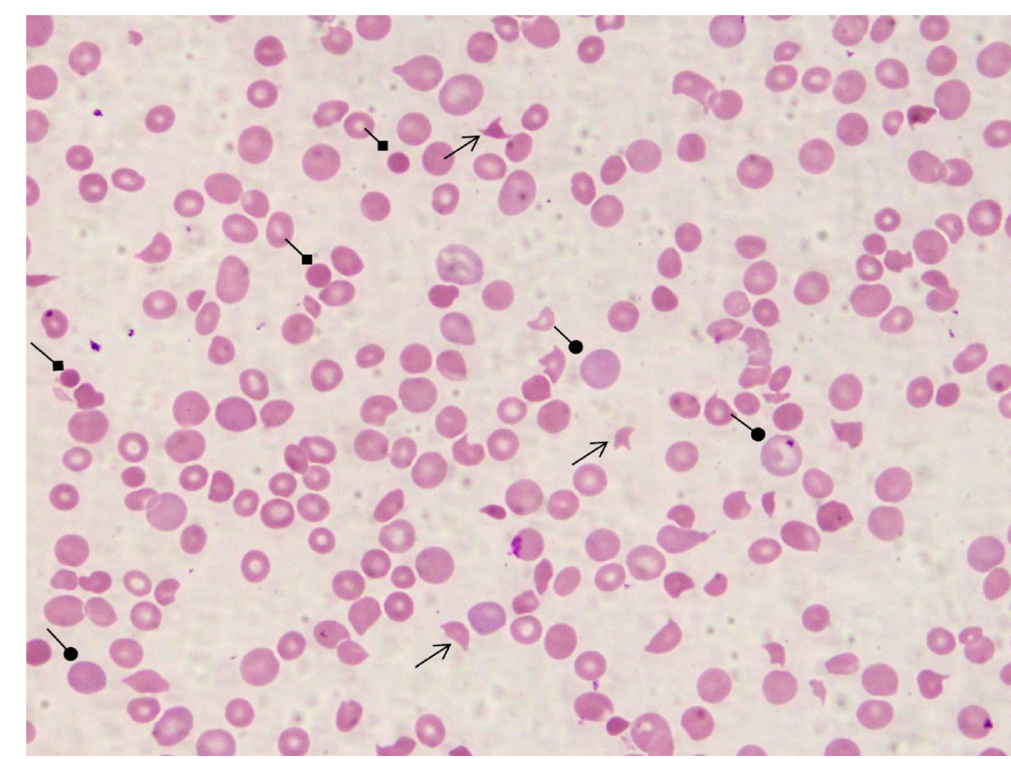

Fig. 1 The peripheral blood film shows presence of fragmented red cells (pointed-head arrow), spherocytes (diamond-head arrow), increased polychromasia (round-head arrow), and thrombocytopenia 
Table 1 Laboratory investigation findings of the patient

Laboratory investigation findings of the patient

\begin{tabular}{|c|c|c|c|c|c|c|c|c|c|c|c|c|}
\hline Date & $\begin{array}{l}06.06 .14 \\
(13 \\
\text { months } \\
\text { old })\end{array}$ & $\begin{array}{c}18.03 .15 \\
(2 \text { years } \\
\text { old })\end{array}$ & $\begin{array}{c}17.10 .16 \\
\text { (present } \\
\text { admission) }\end{array}$ & 19.10 .16 & 22.10 .16 & 28.10 .16 & 04.11 .16 & 11.11 .16 & 21.11 .16 & 23.11 .16 & 24.11 .16 & 25.11 .16 \\
\hline $\mathrm{Hb}(\mathrm{g} / \mathrm{dL})$ & 9.4 & 11.2 & 7.6 & 6.7 & 6.1 & 6.8 & 6.4 & 7.4 & 8.1 & 11.3 & 8.2 & 8.3 \\
\hline $\operatorname{MCV}(\mathrm{fl})$ & 66.3 & 69.6 & 63.7 & 65.5 & 72.1 & 82.5 & 84.5 & 85.7 & 80.1 & 79.3 & 79.8 & 79.8 \\
\hline $\mathrm{MCH}(\mathrm{pg})$ & 20.7 & 22.1 & 21.1 & 21.8 & 23.0 & 24.8 & 25.4 & 26.4 & 24.8 & 24.6 & 24.4 & 24.3 \\
\hline TWC $\left(x 10^{9} / \mathrm{L}\right)$ & 17.1 & 19.9 & 7.1 & 7.0 & 5.0 & 8.2 & 11.6 & 11.4 & 16.8 & 16.6 & 16.0 & 15.7 \\
\hline Platelets $\left(\times 10^{9} / \mathrm{L}\right)$ & 229 & 212 & 20 & 13 & 22 & 26 & 12 & 34 & 46 & 74 & 177 & 241 \\
\hline Retic $\left(\times 10^{9} / \mathrm{L}\right)$ & & & & 128.6 & 217.3 & 357.6 & 292.3 & 315.8 & - & 260.8 & 171.4 & 136.7 \\
\hline
\end{tabular}

$\begin{array}{lll}\text { S. Iron (umol/L) } & 2.8 & 3.8 \\ & 63 & 62\end{array}$

\begin{tabular}{|c|c|c|c|c|c|c|c|c|}
\hline & 1085 & 958 & & & & 451 & 365 & 337 \\
\hline 13.7 & & & & & & 14.3 & & \\
\hline 37.5 & & & & & & 25.3 & & \\
\hline 1.06 & & & & & & 1.15 & & \\
\hline & & 3.56 & & & & 3.24 & & \\
\hline & & 2.8 & & & & 2.8 & & \\
\hline 3.7 & 3.0 & 4.0 & 3.4 & 4.4 & 4.4 & & & \\
\hline 40.2 & 36.5 & 42.6 & 41.6 & 45.9 & 50.4 & & & \\
\hline 16.9 & & & & & 8.3 & 4.8 & & \\
\hline 134 & & & & & 55 & 70 & & \\
\hline
\end{tabular}

Total bilirubin (umol/L)

$\operatorname{ALT}(\mathrm{U} / \mathrm{L})$

0.05

ADAMTS13

Activity (\%)

ADAMTS13

0

$>93.41 \%$

Inhibitor $(\mathrm{U} / \mathrm{mL})$

\begin{tabular}{|c|c|c|c|c|c|c|c|c|c|c|c|c|}
\hline Tests & 02.12 .16 & 09.12 .16 & 22.12 .16 & 29.12 .16 & 17.01 .17 & 14.02 .17 & 14.03 .17 & 17.04 .17 & 05.09 .17 & 23.10 .17 & 04.12 .17 & 15.02 .18 \\
\hline $\mathrm{Hb}(\mathrm{g} / \mathrm{dL})$ & 9.3 & 9.3 & 10.4 & 10.5 & 11.8 & 11.7 & 11.6 & & 12.2 & 12.6 & 13.2 & \\
\hline $\operatorname{MCV}(\mathrm{fl})$ & 76.3 & 73.6 & 71.0 & 68.0 & 67.8 & 65.3 & 66.3 & & 69.3 & 69.2 & 71.0 & \\
\hline $\mathrm{MCH}(\mathrm{pg})$ & 23.7 & 23.0 & 22.0 & 21.6 & 31.3 & 31.6 & 20.5 & & 21.6 & 22.0 & 22.1 & \\
\hline $\operatorname{TWC}\left(\times 10^{9} / \mathrm{L}\right)$ & 13.4 & 12.9 & 14.1 & 13.2 & 13.8 & 12.2 & 12.8 & & 7.7 & 10.6 & 9.7 & \\
\hline Platelets $\left(\times 10^{9} / \mathrm{L}\right)$ & 595 & 218 & 472 & 369 & 386 & 307 & 431 & & 362 & 283 & 461 & \\
\hline Retic $\left(\times 10^{9} / \mathrm{L}\right)$ & & & & & 36.1 & 36.3 & 31.8 & & 46.2 & - & 45.9 & \\
\hline \multicolumn{13}{|l|}{ S. Iron $(u m o l / L)$} \\
\hline \multicolumn{13}{|l|}{ TIBC (umol/L) } \\
\hline LDH (U/L) & & & & & 306 & 271 & & & & & 190 & \\
\hline \multicolumn{13}{|l|}{ PT (s) } \\
\hline \multicolumn{13}{|l|}{$\operatorname{APTT}(\mathrm{s})$} \\
\hline \multicolumn{13}{|l|}{ INR } \\
\hline \multicolumn{13}{|l|}{ D-dimer (ug/ml) } \\
\hline \multicolumn{13}{|l|}{ Fibrinogen $(\mathrm{g} / \mathrm{L})$} \\
\hline \multicolumn{13}{|l|}{ Urea $(\mathrm{mmol} / \mathrm{L})$} \\
\hline \multicolumn{13}{|l|}{ Creatinine (umol/L) } \\
\hline \multicolumn{13}{|c|}{ Total bilirubin $(\mathrm{umol} / \mathrm{L})$} \\
\hline \multicolumn{13}{|l|}{$\operatorname{ALT}(\mathrm{U} / \mathrm{L})$} \\
\hline \multicolumn{13}{|l|}{ CRP } \\
\hline ADAMTS13 & & & & & & & & 20.4 & 48 & & 103 & $>114$ \\
\hline \multicolumn{13}{|l|}{ Activity (\%) } \\
\hline ADAMTS13 & & & & & & & & 14 & 17.5 & & 18 & not done \\
\hline Inhibitor $(\mathrm{U} / \mathrm{mL})$ & & & & & & & & & & & & \\
\hline
\end{tabular}


Table 2 Additional laboratory investigation findings of the patient

\begin{tabular}{|c|c|c|c|c|c|}
\hline Investigations & $17 / 10 / 16$ & 20/10/16 & $11 / 11 / 16$ & $14 / 11 / 16$ & $14 / 02 / 17$ \\
\hline Blood culture and sensitivity & No growth & & & & \\
\hline Dengue NS1 antigen & Non-reactive & & & & \\
\hline Dengue IgM & Negative & & & & \\
\hline Dengue $\lg G$ & Negative & & & & \\
\hline Mycoplasma pneumoniae lgM & Negative & & & & \\
\hline Mycoplasma pneumoniae lgG & $1 / 80$ & & & & \\
\hline Epstein-Barr virus IgM & Negative & & & & \\
\hline Epstein-Barr virus IgG & Positive & & & & \\
\hline Parvovirus lgM & Negative & & & & \\
\hline Parvovirus lgG & Negative & & & & \\
\hline RPR/NDRL & & & & Non-reactive & \\
\hline HBsAg & & & & Non-reactive & \\
\hline Anti-HCV & & & & Non-reactive & \\
\hline HIV antigen and antibody & & & & Non-reactive & \\
\hline Complement 3 (mg/dL) (NR, 39-180) & & 109 & & & 136 \\
\hline Complement 4 (mg/dL) (NR, 10-40) & & 18.4 & & & 18.7 \\
\hline Anti-nuclear antibody (ELISA) & & Positive & & & Positive \\
\hline Anti-nuclear antibody (IF) & & $\begin{array}{l}\text { Positive }(1 / 640) \\
\text { Pattern: speckled }\end{array}$ & & & $\begin{array}{l}\text { Positive }(1 / 640) \\
\text { Pattern: speckled }\end{array}$ \\
\hline Anti-double-stranded DNA (ELISA) & & Negative & & & Borderline \\
\hline Immunoglobulin A (mg/dL) (NR, 70-400) & & 187 & & & \\
\hline Immunoglobulin M (mg/dL) (NR, 40-230) & & 87.2 & & & \\
\hline Immunoglobulin G (mg/dL) (NR, 700-1600) & & 1600 & & & \\
\hline Direct Coombs test & & Negative & & & \\
\hline Indirect Coombs test & & Negative & & & \\
\hline Erythrocyte sedimentation rate (mm/hour) & & & 115 & & \\
\hline Prothrombin time (seconds) (NR, 11.9-14.0) & & & 14.2 & & 13.7 \\
\hline Thrombin time (seconds) (NR, 12-21) & & & 16.7 & & 16.1 \\
\hline Fibrinogen (g/L) (NR, 1.36-4.65) & & & 2.58 & & 2.60 \\
\hline PTT LA & & & 48.5 & & 42.4 \\
\hline DRW screen (seconds) (NR, 28-46.3) & & & 41.7 & & 37.9 \\
\hline DRW screen ratio & & & 1.04 & & 0.92 \\
\hline Anti-cardiolipin IgM (U/mL) (NR, 0-20) & & & 3.9 & & \\
\hline Anti-cardiolipin lgG (U/mL) (NR, 0-20) & & & 9.6 & & \\
\hline Anti-beta2 glycoprotein 1 lgM (U/mL) (NR, 0-20) & & & 2.7 & & 1.1 \\
\hline Anti-beta2 glycoprotein $1 \mathrm{lgG}(\mathrm{U} / \mathrm{mL})(\mathrm{NR}, 0-20)$ & & & 43.5 & & 12.3 \\
\hline \multicolumn{6}{|l|}{ Nuclear antibodies } \\
\hline SmD & & & Negative & & \\
\hline RNP-70 K & & & Negative & & \\
\hline RNP-A & & & Negative & & \\
\hline RNP-C & & & Negative & & \\
\hline SSA(Ro52) & & & Negative & & \\
\hline SSA(Ro60) & & & Negative & & \\
\hline $\operatorname{SSB}(\mathrm{La})$ & & & Negative & & \\
\hline
\end{tabular}


Table 2 Additional laboratory investigation findings of the patient (Continued)

\begin{tabular}{|c|c|c|c|c|c|}
\hline Investigations & $17 / 10 / 16$ & 20/10/16 & $11 / 11 / 16$ & $14 / 11 / 16$ & $14 / 02 / 17$ \\
\hline Cenp-B & & & Negative & & \\
\hline Topo-1(Scl-70) & & & Negative & & \\
\hline Ribosomal P & & & Negative & & \\
\hline Histone & & & Negative & & \\
\hline SmB & & & Negative & & \\
\hline Jo-1(HRS) & & & Negative & & \\
\hline
\end{tabular}

Cenp- $B$ centromere protein $B, D R V V$ dilute Russell's viper venom test, ELISA enzyme-linked immunosorbent assay, $H B s A g$ hepatitis $B$ surface antigen, $H C V$ hepatitis $C$ virus, HIV human immunodeficiency virus, IF immunofluorescent, Jo-1(HRS) histidyl-tRNA synthetase, NR normal range, NS1 nonstructural protein $1, P T T$ LA prothrombin time lupus anticoagulant, RNP ribonucleoprotein, RPR/VDRL rapid plasma reagin/Venereal Disease Research Laboratory, Sm Smith protein, SSA(Ro) Sjögren's syndrome-related antigen A, SSB(La) Sjögren's syndrome-related antigen B, Topo-1(SCl-70) topoisomerase 1

inhibitor, $93.15 \mathrm{U} / \mathrm{mL}$ (negative $<12 \mathrm{U} / \mathrm{mL}$; borderline $12-15 \mathrm{U} / \mathrm{mL}$; positive $>15 \mathrm{U} / \mathrm{mL}$ ) confirming the diagnosis of secondary TTP. Other laboratory investigations to identify specific secondary causes of TTP were negative: (i) viral studies on parvovirus, Epstein-Barr virus, and dengue virus; and (ii) blood culture and sensitivity. The screening for autoimmune disease showed anti-nuclear antibody positive and borderline double-stranded deoxyribonucleic acid (DNA), however, complement 3 and complement 4 levels were normal. He had no clinical findings to suggest connective tissue disease. He received fresh frozen plasma (FFP) transfusions (10-15 ml/kg per day) for 3 consecutive days. His hemoglobin $(\mathrm{Hb})$ level was $8.1 \mathrm{~g} / \mathrm{dL}$ and platelet count was $46 \times 10^{9} / \mathrm{L}$ prior to the transfusions. Subsequently, the counts recovered. He had a $\mathrm{Hb}$ level of $8.1 \mathrm{~g} / \mathrm{dL}$ and platelet count of $168 \times 10^{9} / \mathrm{L}$, a day after completed FFP transfusions. His reticulocytes count and $\mathrm{LDH}$ level reduced to $4.0 \%$ and $337 \mathrm{U} / \mathrm{L}$, respectively. Six months later, the ADAMTS13 activity improved to 20.5\%, and ADAMTS13 inhibitor reduced markedly to $14 \mathrm{U} / \mathrm{mL}$. At 12 months, he remained in clinical remission, the ADAMTS13 activity had normalized to $48 \%$; however, the ADAMTS13 inhibitor level was still detectable at $17.5 \mathrm{U} / \mathrm{mL}$. He was given orally administered prednisolone $1 \mathrm{mg} / \mathrm{kg}$ per day for 6 weeks and it was tapered off 2 weeks later. A repeated ADAMTS13 activity at the end of the prednisolone course was $>114 \%$. However, there was no result available about the inhibitor level. He is scheduled for follow-up every 3 months with surveillance of ADAMTS13 assay for 1 year. During clinic follow-up at 6 months after treatment, he remained in remission and his full blood counts were normal. A timeline for our patient is given in Fig. 2.

\section{Discussion}

Our case report describes a very young boy with acquired TTP who presented with febrile seizure during an infection, and had no clinical evidence of neurological deficit at presentation. Laboratory investigations revealed MAHA, thrombocytopenia, elevated serum, and LDH, and an ADAMTS13 assay confirmed secondary TTP. He recovered with treatment of plasma infusion and corticosteroid, and did not receive the standard treatment of plasmapheresis.

In children, acquired TTP is very uncommon and can be life-threatening $[1,3]$. TTP is diagnosed when the classic pentad of fever, MAHA, thrombocytopenia, neurologic manifestation, and elevated creatinine are present. However, not all signs are observed at initial presentation and the disease varies in severity [1-3]. The Oklahoma TTP-HUS (hemolytic-uremic syndrome) Registry reported that the incidence rate of TTP in children was $2.24 \times 10^{6}$ children/year [1]; acquired TTP has an annual incidence rate of $0.09 \times 10^{6}$ children/year [1] A cohort study of the French national registry for thrombotic microangiopathy reported a prevalence of 1 case per 1 million children for childhood-onset acquired TTP [3]. Acquired TTP was reported to be more common among older children (9-17 years of age) and female gender [1, 3]. However, we report here a very young boy with acquired TTP following an episode of febrile seizure with skin infection. In children, acquired TTP is often misdiagnosed initially as idiopathic thrombocytopenic purpura, Evans syndrome, atypical HUS (aHUS), or malignancy. HUS and TTP share a common underlying pathological process of thrombotic microangiopathy with detection of schistocytes in the peripheral blood smear. HUS is defined as the triad of MAHA, thrombocytopenia, and acute kidney injury. In typical diarrhea-associated HUS, the clinical manifestation frequently follows a prodromal hemorrhagic enterocolitis. In aHUS, abdominal pain and diarrhea are usually absent and the presentations could mimic TTP. However, the distinction between aHUS and TTP can be made by performing molecular genetics [6]. Genetic or acquired aHUS is associated with mutation within the gene coding for regulatory components for the complement system. TTP is diagnosed by reduction in ADAMTS13 activity [7]. Delay in diagnosis of TTP in children could result in severe consequences. We did not find any secondary causes in our patient. However, one should be aware that this condition is sometimes associated with 


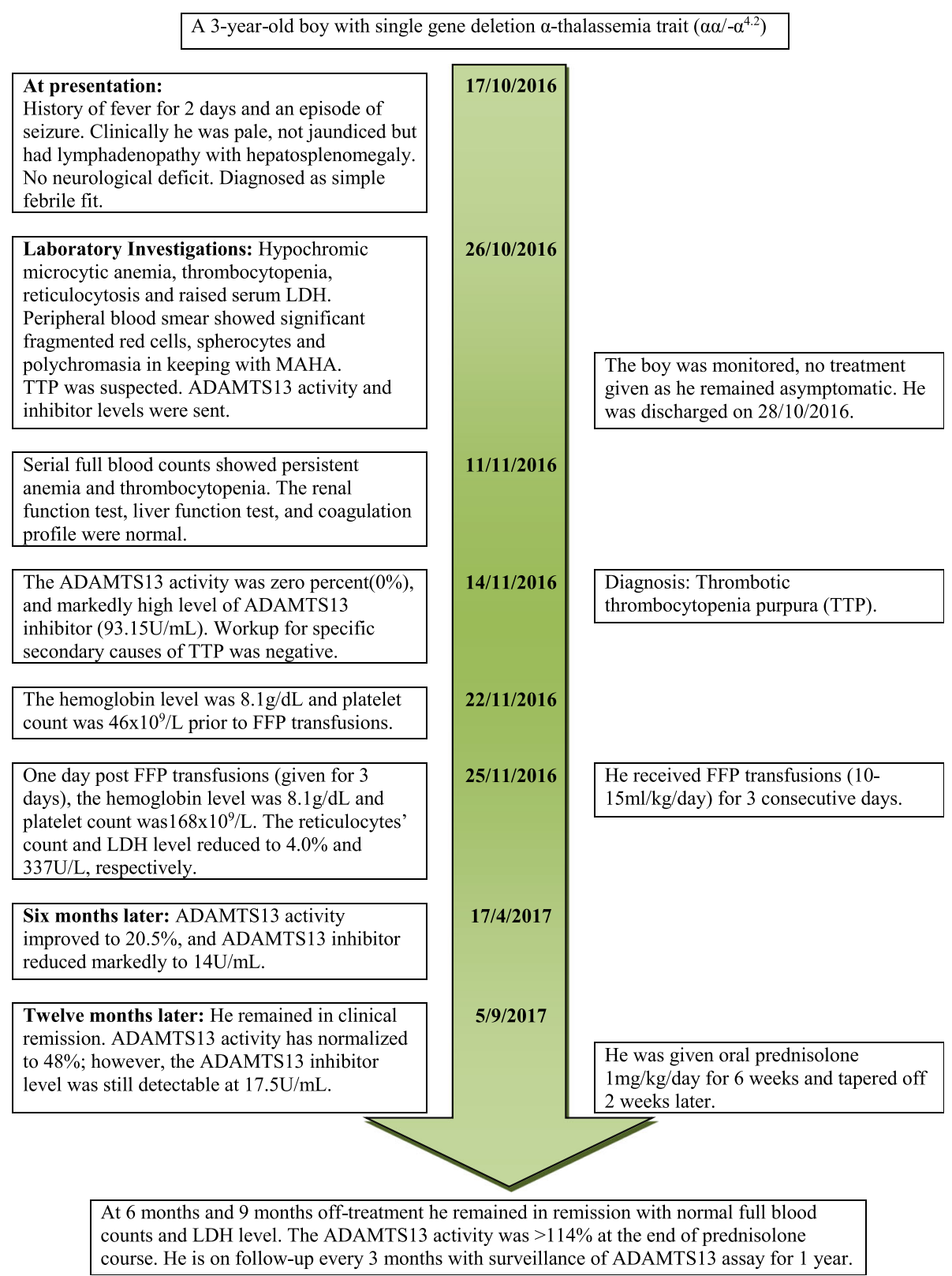

Fig. 2 Timeline of illness. ADAMTS13 a disintegrin and metalloproteinase with a thrombospondin type 1 motif, member 13, FFP fresh frozen plasma, LDH lactate dehydrogenase, MAHA microangiopathic hemolytic anemia, TTP thrombotic thrombocytopenia purpura

other clinical problems in children such as diabetic ketoacidosis, acute lymphocytic leukemia, or viral infections [8, 9]. In acquired TTP, antibodies toward ADAMTS13 may develop idiopathically or in association with another autoimmune condition or connective tissue disease [1, 2, 4]. Brunner et al. reported that $26 \%$ of 35 patients with TTP had systemic lupus erythematosus (SLE), and an additional 23\% had incipient SLE [10]. Despite the negative findings of an autoimmune condition in our patient, regular monitoring is needed during follow-up. Some patients were reported to develop SLE or other autoimmune states after the diagnosis of TTP.

Plasma exchange is the mainstay of treatment for acquired TTP, to remove the autoantibody against ADAMTS13 and the ultra-large vWF, while replacing the missing protease in the patient $[1,2,4,11]$. Recently, a study reported benefits of plasma transfusions in some patients with TTP when $70-80 \%$ of them achieved remission [12]. It is interesting to note that our patient's condition resolved with FFP transfusions and steroid. 
However, plasma transfusions alone could be hampered by fluid overload and proteinuria in patients [11, 12]. Hence, in the setting where plasma exchange may not be immediately available to patients, plasma transfusions can be effective as a temporary measure [11, 12]. Recent developments in therapeutic options for TTP include the use of caplacizumab (an anti-vWF immunoglobulin) and recombinant ADAMTS13 [13-15]. In a life-threatening condition, clinical presentation and the triad findings are often sufficient to diagnose TTP and justify emergency treatment $[2,4]$. At the same time, initial measurement of ADAMTS13 activity is vital and should be done to confirm the diagnosis $[2,4,16]$. In patients with very low ADAMTS13 level and high level of ADAMTS13 inhibitor, the risk of relapse was threefold greater than those with higher ADAMTS13 level and without inhibitor $[17,18]$. Regular follow-up to monitor the clinical condition, platelet count, and LDH, and ADAMTS13 assay is crucial to detect relapse, and prompt treatment could avoid mortality [17-19].

\section{Conclusions}

Acquired TTP is very rare among young children and often misdiagnosed at presentation. When a child presents with febrile seizure, MAHA, thrombocytopenia, and elevated LDH, TTP should be suspected. ADAMTS13 assay should be performed early as this condition is associated with dire consequences.

\section{Abbreviations \\ ADAMTS13: A disintegrin and metalloproteinase with a thrombospondin type 1 motif, member 13; aHUS: Atypical hemolytic-uremic syndrome; DNA: Deoxyribonucleic acid; FFP: Fresh frozen plasma; Hb: Hemoglobin; HUS: Hemolytic-uremic syndrome; IgG: Immunoglobulin G; LDH: Lactate dehydrogenase; MAHA: Microangiopathic hemolytic anemia; SLE: Systemic lupus erythematosus; TTP: Thrombotic thrombocytopenia purpura; VWF: von Willebrand factor}

\section{Acknowledgements}

The authors would like to thank Professor Dr Paul Monagle from the Royal Children's Hospital, Melbourne for his expert advice on the management of the patient, and Dr Jameela Satar from Hospital Ampang, Kuala Lumpur for the support on ADAMTS13 assay tests.

\section{Availability of data and materials}

All relevant data are within the manuscript.

\section{Authors' contributions}

HAli and WLY drafted the manuscript. HAli, WLY, HWK, and SCDL acquired the clinical data. HAli, HWK, CKL, and SCDL were responsible for the clinical management of the patient. WLY, FAAM, HAla, and RZA were responsible for the hematological diagnosis. All authors have read and approved the final manuscript.

\section{Ethics approval and consent to participate}

Ethics approval from The National University of Malaysia (UKM) Research Ethics Committee is not required for this report submission. The Research Ethics Committee, The National University of Malaysia operates in accordance to the International Conference of Harmonization Good Clinical Practice Guidelines.

\section{Consent for publication}

Written informed consent was obtained from the patient's legal guardian(s) for publication of this case report and any accompanying images. A copy of the written consent is available for review by the Editor-in-Chief of this journal.

\section{Competing interests}

The authors declare that they have no competing interests.

\section{Publisher's Note}

Springer Nature remains neutral with regard to jurisdictional claims in published maps and institutional affiliations.

\section{Author details}

${ }^{1}$ Department of Pediatrics, UKM Medical Centre, Faculty of Medicine, The National University of Malaysia, Cheras, 56000 Kuala Lumpur, Malaysia. ${ }^{2}$ Department of Pathology, UKM Medical Centre, Faculty of Medicine, The National University of Malaysia, Cheras, 56000 Kuala Lumpur, Malaysia.

Received: 6 April 2018 Accepted: 16 August 2018

Published online: 17 September 2018

\section{References}

1. Reese JA, Muthurajah DS, Kremer Hovinga JA, Vesely SK, Terrell DR, George JN. Children and adults with thrombotic thrombocytopenic purpura associated with severe, acquired ADAMTS13 deficiency: comparison of incidence, demographic and clinical features. Pediatr Blood Cancer. 2013;60:1676-82.

2. Loirat C, Coppo P, Veyradier A. Thrombotic thrombocytopenic purpura in children. Curr Opin Pediatr. 2013;25(2):216-24.

3. Joly BS, Stepanian A, Leblanc T, Hajage D, Chambost H, Harambat J, et al. Child-onset and adolescent-onset acquired thrombotic thrombocytopenic purpura with severe ADAMTS13 deficiency: a cohort study of the French national registry for thrombotic microangiopathy. Lancet Haematol. 2016; 3(11):e537-46.

4. Lowe EJ, Werner EJ. Thrombotic thrombocytopenic purpura and hemolytic uremic syndrome in children and adolescents. Semin Thromb Hemost. 2005;31(6):717-30.

5. NIH, US National Library of Medicine. Genetic Home References: ADAMTS13 gene, ADAM metallopeptidase with thrombospondin type 1 motif 13. Bethesda: Lister Hill National Center for Biomedical Communications, US National Library of Medicine; 2017. https://ghr.nlm.nih.gov/gene/ADAMTS13

6. Trachtman H. HUS and TTP. Pediatr Clin N Am. 2013;60(6):1513-26.

7. Noris M, Mescia F, Remuzzi G. STEC-HUS, atypical HUS and TTP are all diseases of complement activation. Nat Rev Nephrol. 2012;8(11):622-33. https://doi.org/10.1038/nrneph.2012.195. Epub 2012 Sept 18

8. Mostofizadeh N, Arefnia S, Hashemipour M, Dehkordi EH. Thrombotic thrombocytopenic purpura in a child with diabetic ketoacidosis. Adv Biomed Res. 2018:7:33.

9. De Leonardis F, Koronica R, Daniele RM, Santoro N. Thrombotic thrombocytopenic purpura in a child treated for acute lymphoblastic leukemia: case report and review of literature. J Pediatr Hematol Oncol. 2017; https://doi.org/10.1097/MPH.0000000000001050. [Epub ahead of print]

10. Brunner HI, Freedman M, Silverman ED. Close relationship between systemic lupus erythematosus and thrombotic thrombocytopenic purpura in childhood. Arthritis Rheum. 1999:42(11):2346-55.

11. Rock GA, Shumak KH, Buskard NA, Blanshette VS, Kelton JG, Nair RC, et al. Comparison of plasma exchanges with plasma infusion in the treatment for TTP. Canadian Apheresis Study Group. N Engl J Med. 1991;325(6):393-7.

12. Coppo P, Bussel A, Charrier S, Adrie C, Galicier L, Boulanger E, et al. Highdose plasma infusion versus plasma exchange as early treatment of thrombotic thrombocytopenic purpura/hemolytic-uremic syndrome. Medicine (Baltimore). 2003;82(1):27-38.

13. Peyvandi F, Scully M, Hovinga JAK, et al. Caplacizumab for acquired thrombotic thrombocytopenic purpura. N Engl J Med. 2016;374:511-22.

14. Tersteeg C, Verhenne S, Roose E, et al. ADAMTS13 and anti-ADAMTS13 autoantibodies in thrombotic thrombocytopenic purpura - current perspectives and new treatment strategies. Expert Rev Hematol. 2016:9(2):209-21.

15. Scully M, Knöbl P, Kentouche $K$, et al. Recombinant ADAMTS-13: first-in-human pharmacokinetics and safety in congenital thrombotic thrombocytopenic purpura. Blood. 2017;130(19):2055-63. 
16. Hassan S, Westwood JP, Ellis D, Laing C, Mc Guckin S, Benjamin S, Scully M. The utility of ADAMTS13 in differentiating TTP from other acute thrombotic microangiopathies: results from the UK TTP registry. $\mathrm{Br} J$ Haematol. 2015:171(5):830-5.

17. Peyvandi F, Lavoretano S, Palla R, Feys HB, Vanhoorelbeke K, Battagliolo T, et al. ADAMTS13 and anti-ADAMTS13 antibodies as markers for recurrence of acquired thrombotic thrombocytopenic purpura during remission. Haematologica. 2008;93(2):232-9.

18. Kremer Hovinga JA, Vesely SK, Terrell DR, Lämmle B, George JN. Survival and relapse in patients with thrombotic thrombocytopenic purpura. Blood. 2010;115(8):1500-11.

19. Bettoni G, Palla R, Valsecchi C, Consonni D, Lotta LA, Trisolini SM, et al. ADAMTS-13 activity and autoantibodies classes and subclasses as prognostic predictors in acquired thrombotic thrombocytopenic purpura. J Thromb Haemost. 2012:10(8):1556-65.

Ready to submit your research? Choose BMC and benefit from:

- fast, convenient online submission

- thorough peer review by experienced researchers in your field

- rapid publication on acceptance

- support for research data, including large and complex data types

- gold Open Access which fosters wider collaboration and increased citations

- maximum visibility for your research: over $100 \mathrm{M}$ website views per year

At BMC, research is always in progress.

Learn more biomedcentral.com/submissions 